\title{
Methanocalculus taiwanensis sp. nov., isolated from an estuarine environment
}

\footnotetext{
${ }^{1}$ Department of Botany, National Chung Hsing University, Taichung, 40227 Taiwan, Republic of China

${ }^{2}$ Food Research \& Development Institute, Hsinchu, Taiwan, Republic of China
}

\author{
Mei-Chin Lai,, ${ }^{1}$ Sheng-Chung Chen, ${ }^{1}$ Chin-Ming Shu, ${ }^{1}$ Ming-Shing Chiou, ${ }^{2}$ \\ Chia-Chi Wang, ${ }^{1}$ Ming-Jen Chuang, ${ }^{1}$ Tong-Yung Hong, ${ }^{1}$ Chia-Chi Liu, ${ }^{1}$ \\ Li-Jane Lai ${ }^{1}$ and Jack Jay Hua ${ }^{2}$
}

Author for correspondence: Mei-Chin Lai. Tel: +886 422840419 ext. 612. Fax: +886 422874740.
e-mail: mclai@dragon.nchu.edu.tw

Two novel hydrogenotrophic methanogens, designated strains P2F9704a' and P2F9705, were isolated from an estuary in Eriln Shi, Taiwan. The cells of strain P2F9704a' were non-motile, irregular cocci 0.9-1.4 $\mu \mathrm{m}$ in diameter. They stained Gram-negative. The cells catabolized formate and $\mathrm{H}_{2}+\mathrm{CO}_{2}$ to produce methane, but did not utilize acetate, methanol, trimethylamine, ethanol or secondary alcohols as methanogenic substrates. The optimal growth parameters for strain P2F9704a' ${ }^{\top}$ were pH 6.7, $37{ }^{\circ} \mathrm{C}$ and 0.5\% NaCl. Acetate was required for cell growth even though it was not a substrate for methanogenesis. The trace element tungsten was not required but slightly stimulated the growth of strain P2F9704a'. However, tungsten extended the growth ranges relating to temperature, pH and salt. The sequences of the 16S rRNA genes of strains P2F9704a' and P2F9705 were nearly identical and possessed $99 \cdot 1$ and $98.5 \%$ similarity to the genes of Methanocalculus pumilus and Methanocalculus halotolerans, respectively. In addition, strain P2F9704a' possessed 14 and $12 \%$ DNA relatedness with respect to Methanocalculus pumilus and Methanocalculus halotolerans, respectively. In addition, the optimal salt concentrations, the cellular protein profiles and the molecular masses of surface-layer protein subunits of strain P2F9704a' were different from those of the other two known Methanocalculus species. On the basis of these observations, it is proposed that these two organisms should be placed in a new species, namely Methanocalculus taiwanensis. The type strain is P2F9704a'

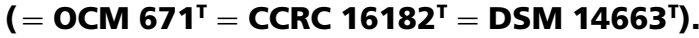

Keywords: archaea, methanogen, Methanocalculus, estuarine, tungsten

\section{INTRODUCTION}

Strictly anaerobic methanogens are the only archaea that are truly ubiquitous. Methanogenic species have been isolated from virtually every habitat in which anaerobic biodegradation of organic compounds occurs, including freshwater and marine sediments, the digestive and intestinal tracts of animals, and anaerobic waste digesters (Boone et al., 1993b; Ferry, 1997; Jones et al., 1987; Wolfe, 1996). Moreover, isolates have also been obtained from extreme environ-

Published online ahead of print on 7 June 2002 as DOI 10.1099/ ijs.0.01730-0.

The GenBank accession numbers for the 16S rDNA sequences of strains P2F9704a ${ }^{\top}$ and P2F9705 are AF172443 and AF411470, respectively. ments such as geothermal springs, deep-sea hydrothermal vents and hypersaline environments (Boone et al., 1993a; Jones et al., 1983; Huber et al., 1982; Ollivier et al., 1994; Stetter et al., 1993).

The order Methanomicrobiales comprises three families (Methanomicrobiaceae, Methanocorpusculaceae and Methanospirillaceae) and nine genera (Boone et al., 1993b; Rouvière et al., 1992) of hydrogenotrophic methanogens (Garcia et al., 2000). The family Methanomicrobiaceae contains seven genera, i.e. Methanomicrobium, Methanolacinia, Methanogenium, Methanoculleus, Methanoplanus, Methanofollis and Methanocalculus. The morphology of cells in the family Methanomicrobiaceae includes small rods, highly irregular cocci, and plane-shaped cells. The cell walls are proteinaceous. All strains can use $\mathrm{H}_{2}+\mathrm{CO}_{2}$ 
and formate as substrates of methanogensis. In addition, some can use secondary alcohols (Garcia et al., 2000). Among them is Methanocalculus, a newly described genus that was first proposed by Ollivier et al. (1998); it encompasses the irregular cocci of Methanocalculus halotolerans, which was isolated from an offshore oil well. Methanocalculus halotolerans grows optimally at $5 \% \mathrm{NaCl}$ but tolerates $\mathrm{NaCl}$ concentrations from 0 to $12 \%$. This growth range is the widest reported, to date, for any hydrogenotrophic methanogen (Garcia et al., 2000; Ollivier et al., 1998). Recently, another Methanocalculus species (Methanocalculus pumilus) was isolated from a waste-disposal site in Japan. It grows optimally at $1 \% \mathrm{NaCl}$ and tolerates only concentrations up to $7 \% \mathrm{NaCl}$ (Mori et $a l ., 2000)$. Here, we report the isolation and characterization of two new Methanocalculus isolates, strains $\mathrm{P} 2 \mathrm{~F} 9704 \mathrm{a}^{\mathrm{T}}$ and P2F9705, from the estuarine environment of Eriln Shi, Taiwan.

\section{METHODS}

Source of organisms. Methanocalculus pumilus MHT- $1^{\mathrm{T}}$ $\left(=\right.$ DSM $\left.12632^{\mathrm{T}}=\mathrm{JCM} 10627^{\mathrm{T}}\right)$ was kindly provided by Dr Koji Mori of Gifu University, Japan. Methanocalculus halotolerans SEBR $4845^{\mathrm{T}}$ (= OCM $470^{\mathrm{T}}$ ) was obtained from the Oregon Collection of Methanogens, USA.

Sampling site. The sampling site was the estuary environment at Eriln Shi, Taiwan. The water temperature in this subtropical environment was $30-34{ }^{\circ} \mathrm{C}$ during the summer, and the salinity at this estuary was around $1 \%(\mathrm{w} / \mathrm{v})$. The sample was collected in a stainless steel sampling basket. From there, it was immediately transferred to a sterile OakRidge bottle that had been equilibrated overnight inside a Coy anaerobic chamber with an $\mathrm{N}_{2} / \mathrm{CO}_{2}$ ratio of $4: 1$. The sample was then transported (within $3 \mathrm{~h}$ ) to the laboratory under anoxic conditions.

Media and culture techniques. The modified anaerobic technique of Hungate was utilized (Balch et al., 1979; Sowers \& Noll, 1995). Sterilized media were prepared under an oxygen-free $\mathrm{N}_{2} / \mathrm{CO}_{2}(4: 1)$ atmosphere. The $\mathrm{MB}$ medium used contained the following (per litre deionized water): $\mathrm{MgCl}_{2} .6 \mathrm{H}_{2} \mathrm{O}, 1.0 \mathrm{~g} ; \mathrm{KCl}, 0.5 \mathrm{~g}$; NaCl, $5 \mathrm{~g}$; $\mathrm{CaCl}_{2} .2 \mathrm{H}_{2} \mathrm{O}$, $0.1 \mathrm{~g} ; \mathrm{K}_{2} \mathrm{HPO}_{4}, 0.4 \mathrm{~g} ; \mathrm{NH}_{4} \mathrm{Cl}, 1.0 \mathrm{~g}$; cysteine. $\mathrm{HCl}, 0.25 \mathrm{~g}$; $\mathrm{NaHCO}_{3}, 4.0 \mathrm{~g}$; yeast extract, $2 \mathrm{~g}$; tryptone, $2 \mathrm{~g}$; and resazurin, 0.001 g. Vitamin (Wolin et al., 1963) and traceelement (Ferguson \& Mah, 1983) solutions without tungstate were each added to a final concentration of $1 \%(\mathrm{v} / \mathrm{v})$. The $\mathrm{pH}$ of the $\mathrm{MB}$ medium was $7 \cdot 0$. An $\mathrm{MB} / \mathrm{W}$ medium was made from $\mathrm{MB}$ medium prepared with a $1 \%(\mathrm{v} / \mathrm{v})$ traceelement solution containing tungstate $\left(\mathrm{Na}_{2} \mathrm{WO}_{4}, 0 \cdot 3 \mathrm{mg} \mathrm{l}{ }^{-1}\right)$. MM medium was MB medium without the addition of yeast extract and tryptone. All of the constituents except sulfide were dissolved in water, boiled and then cooled under an oxygen-free $\mathrm{N}_{2} / \mathrm{CO}_{2}(4: 1)$ atmosphere. The medium was distributed into serum bottles (Wheaton Scientific) or Hungate tubes (Belleco Glass) under the same atmosphere. The anaerobic tubes were then sealed and autoclaved at $121^{\circ} \mathrm{C}$ for $20 \mathrm{~min}$. Sodium sulfide from a sterilized anoxic stock solution was added to a final concentration of $1 \mathrm{mM}$ before inoculation. For solid roll-tube medium, agar was added at $20 \mathrm{~g} \mathrm{l}^{-1}$. To measure the effect of $\mathrm{pH}$ on growth, the ratio of $\mathrm{N}_{2}$ to $\mathrm{CO}_{2}$ in the gas phase and the concentration of
$\mathrm{NaHCO}_{3}$ in the medium were modified to obtain $\mathrm{pH}$ values between $5 \cdot 6$ and $8 \cdot 3$.

Enrichment and isolation. The enrichment was begun immediately after the sample had been brought to the laboratory. In an anaerobic chamber, the estuarine water sample $(5 \mathrm{ml})$ was added to $160 \mathrm{ml}$ serum bottles that contained $45 \mathrm{ml} \mathrm{MB}$ medium with sodium formate $(50 \mathrm{mM})$ as the catabolic substrate. Vancomycin $\left(100 \mathrm{mg}^{-1}\right)$ was added to inhibit the growth of non-methanogenic organisms. The culture was incubated in the dark at room temperature for one month. A large amount of methane was detected in the cultures; $5 \mathrm{ml}$ culture was then transferred anaerobically into a new bottle of sterile MB medium with formate. This procedure was repeated for four successive transfers. The culture was then diluted and transferred into molten MB agar, and the roll-tube technique was performed. Colonies grew on the inner wall of the glass tube after 2-3 weeks. In a Coy anaerobic chamber, colonies were picked with disposable, sterilized inoculation needles and transferred to anaerobic tubes containing $5 \mathrm{ml} \mathrm{MB}$ medium. Cultures from a single colony were further incubated at $30^{\circ} \mathrm{C}$ for $1-2$ weeks. Two methane-producing cultures, derived from two morphological distinct colonies, were furthered purified with repeated serial dilutions with vancomycin until it was free of contamination by non-methanogenic bacteria. The axenic nature of the culture was established on the basis of microscopic examination, the presence of a single colony type in roll tubes, and the absence of growth in anaerobically prepared Bacto thioglycollate medium.

Determination of catabolic substrates. The catabolic substrates tested under $\mathrm{N}_{2} / \mathrm{CO}_{2}(4: 1)$ were sodium formate $(100 \mathrm{mM})$, sodium acetate $(50 \mathrm{mM})$, trimethylamine (40 mM), methanol (50 mM), ethanol (48 mM), 2-propanol (48 $\mathrm{mM})$, iso-butanol (48 mM) and 2-butanol (48 mM). $\mathrm{H}_{2}$ was tested for by pressurizing the culture tubes with $\mathrm{H}_{2}$ $(100 \%, 200 \mathrm{kPa})$. Utilization of the substrates was determined in $\mathrm{MB} / \mathrm{W}$ media by monitoring methane production. Methane production was determined by $\mathrm{GC}$ with flame-ionization detection (Lai et al., 1999).

Antibiotic susceptibility. The sensitivity of strain P2F9704a to ampicillin, penicillin, spectinomycin, kanamycin, tetracycline and chloramphenicol (each at a concentration of $100 \mu \mathrm{g} \mathrm{ml}^{-1}$ ) was tested in $\mathrm{MB} / \mathrm{W}$ medium with sodium formate $(100 \mathrm{mM})$ at $37^{\circ} \mathrm{C}$. Growth was determined from methane production.

Whole-cell protein profile and surface-layer protein study. Whole-cell proteins were extracted from cell pellets by adding loading buffer containing $4 \%$ sodium dodecyl sulfate at a ratio of $1 \mathrm{ml}$ buffer per OD unit. An OD unit was the amount of cells found in $1 \mathrm{ml}$ culture with an absorbance of 1.0. Surface-layer proteins were isolated according to the protocol of König (1995). SDS-PAGE was performed as described by Laemmli (1970). Gels were stained with Coomassie blue R-250.

Determination of growth rates. Specific growth rates were calculated from the methane production, which was analysed by linear regression of the logarithm of the total amount of methane that accumulated over time (Lai et al., 2000). Inocula were grown under conditions similar to the experimental conditions

Microscopy. An Olympus BH-2 microscope was used for phase-contrast microscopy. Preparations for negative staining and ultrathin sectioning were performed as described 
previously (Lai \& Shih, 2001). Electron micrographs were taken using a model JEM-1200EXII and 200cx (JEOL) equipment. For scanning electron micrographs, samples were prepared as described previously (Lai \& Chen, 2001), and cells were sputter-coated with gold and observed with a Topcon model ABT-150S scanning electron microscope.

Phylogenetic analysis. DNAs from strains P2F9704a ${ }^{\mathrm{T}}$ and P2F9705 were isolated by the general procedure of Jarrell et al. (1992). Approximately $30 \mathrm{ng}$ DNA was used as a template for PCR amplification of an approximately $1300 \mathrm{bp}$ portion of the 16S rRNA gene. The PCR amplification primers used for strain P2F9704a ${ }^{T}$ were 5'-GCTCAGTAACACGTG GATAACC-3' and 5'-GCAGATTCCCCTACGGCTACC$3^{\prime}$. The sequences were checked by the CHECK-PROBE program from the Ribosomal Database Project (Maidak et al., 1996), and corresponded to positions 20-40 and 1444-1424 in the 16S rDNA (rDNA) nucleotide sequence of Methanocalculus halotolerans SEBR 4845 ${ }^{\mathrm{T}}$ (accession no. AF033672). For strain P2F9705, the PCR amplification primers used were 5'CGACTAAGCCATGCGAGTC - $3^{\prime}$ and $5^{\prime}$-GTGACGGGCGGTGTGTGCAAG-3', which corresponded to positions 34-52 and 1338-1320 in the 16S rDNA nucleotide sequence of Methanocalculus halotolerans. The following primers were also used for sequencing: 5'-GCTCAGTAACACGTGGATAACC-3', 5'-CGAC TAAGCCATGCGAGTC-3', 5'-TAGACTTGGGACCGGGAGAGG-3', 5'-TGGGTCTCGCT CGTTG-3'， 5'-GTGACGGGCGGTGTGTGCAAG-3' and 5'-GCAGATTCCCCTACGGCT ACC-3' (Methanocalculus halotolerans SEBR $4845^{\mathrm{T}}$, sequence positions 20-42, 34-52, 572-592, 979-964, 1338-1320 and 1444-1424, respectively). The resulting sequences were assembled to produce an approximately $1369 \mathrm{bp}$ contiguous rDNA sequence for strain P2F9704a $\mathrm{a}^{\mathrm{T}}$ and $1260 \mathrm{bp}$ sequence for strain P2F9705. The gene sequences of the archaea used were obtained from the GenBank database. The similarity matrix was obtained based on the analytic results of the Ribosomal Database Project (http://rdp.cme.msu.edu.htm/). Multiple sequence alignments were analysed by using the CLUSTAL W package at the Biology Workbench (http://workbench. sdsc.edu/). Distances were computed with the CLUSTAL TREE package at the same website, using the neighbour-joining model, and fed to the program DRAWGRAM of the program package PHYLIP version 3.5c (Felsenstein, 1995). A bootstrap confidence analysis was performed with the SEQBOOT program of the PHYLIP package by using 500 replicates.

DNA-DNA hybridization. Cells of Methanocalculus species were harvested at late exponential phase and used for DNA isolation. DNA was isolated and purified by a modification of the methods of Jarrell et al. (1992) and Johnson (1985). DNA-DNA hybridization experiments were performed by using the dot-blot technique (Sambrook \& Russell, 2001) with a VersiTag fluorescein labelling system (NEN Life Science). Target DNA (500 ng) denatured by $0.8 \mathrm{M} \mathrm{NaOH}$ was blotted on to a Hybond-N + nylon membrane (Amersham Pharmacia Biotech), and the labelled DNA was reassociated in a solution containing $50 \%$ formamide, $5 \times$ Denhardt's solution $(50 \times$ Denhardt's contains $1 \%$ Ficoll, $1 \%$ polyvinylpyrrolidone and $1 \%$ bovine serum albumin) and $0.5 \%(\mathrm{w} / \mathrm{v}) \mathrm{SDS}$ in $5 \times$ standard saline citrate buffer $(1 \times$ standard saline citrate is $0.15 \mathrm{M} \mathrm{NaCl}$ plus $0.015 \mathrm{M}$ sodium citrate). After incubation overnight at $42{ }^{\circ} \mathrm{C}$, the blots were analysed with a Renaissance nucleic acid chemiluminescence reagent with an anti-fluorescein horseradish peroxidase conjugate detection system supplied by NEN Life Science. Hybridization signals were detected by autoradiography. Duplicate tests were performed for each assay, and self-hybridization of the probe with homologous target DNA was set to $100 \%$.

\section{RESULTS}

\section{Enrichment and isolation}

Water samples $(5 \mathrm{ml})$ from the estuarine environment of Eriln Shi, Taiwan, were inoculated into eight bottles of MB medium $(45 \mathrm{ml})$ containing methanol, trimethylamine, acetate or formate as methanogenic substrate. After one month incubation at room temperature, methanogenesis occurred in all enrichments. The formate enrichment was further enriched by four successive transfers, and then this culture was inoculated into roll-tube $\mathrm{MB}$ agar medium for further isolation. Under the fluorescence microscope, two fluorescent-positive colonies were picked and transferred to $5 \mathrm{ml} \mathrm{MB}$ medium with formate in a Coy anaerobic chamber. One was a large, yellowish, circular colony (strain P2F9704a ${ }^{\mathrm{T}}$ ). The other colony possessed an irregular margin (strain P2F9705). Methane-producing cultures from the single colonies were further purified by serial dilution in medium with vancomycin until contamination by non-methanogens was not detectable.

\section{Morphology, S-layer, and cell structure}

Cells of strain P2F9704a ${ }^{\mathrm{T}}$ were non-motile, irregular cocci $0.9-1.4 \mu \mathrm{m}$ in diameter. Strain P2F9705 also comprised irregular cocci, but the cells were motile and possessed flagella. When observed under the scanning electron microscope, the cell shape for strain P2F9704a ${ }^{\mathrm{T}}$ often resembled a soy-sauce dish (Fig. 1a); interestingly, angular edges were observed under negative staining (Fig. 1b). Refractive areas were observed under light microscopy of both strain P2F9704a ${ }^{\mathrm{T}}$ (Fig. 1c) and strain P2F9705.

Both strains stained as Gram-negative and lysed immediately upon the addition of SDS to $0.01 \%$ $(\mathrm{w} / \mathrm{v})$, indicating that a proteinaceous cell wall was present (Boone \& Whitman, 1988). Ultrathin sections of strain P2F9704a ${ }^{\mathrm{T}}$ showed that the S-layer was closely associated with the cytoplasmic membrane (Fig. 1d). In this regard, cells of P2F9704a ${ }^{\mathrm{T}}$ resembled Methanocalculus halotolerans and differed from cells of Methanocalculus pumilus (Mori et al., 2000; Ollivier et al., 1998). The S-layer protein of strain P2F9704a ${ }^{\mathrm{T}}$ was composed by two different subunits, while the S-layers of Methanocalculus halotolerans and Methanocalculus pumilus were composed of only a single subunit. The molecular masses of the S-layer proteins of strain P2F9704a ${ }^{\mathrm{T}}$, Methanocalculus halotolerans and Methanocalculus pumilus were as follows: 112000 and 95100; 91800; and 94300, respectively (see Table 1).

\section{Sensitivity to antibiotics}

Strains P2F9704a ${ }^{\mathrm{T}}$ and $\mathrm{P} 2 \mathrm{~F} 9705$ were both resistant to ampicillin, penicillin, kanamycin, tetracycline and spectinomycin and sensitive to chloramphenicol. 

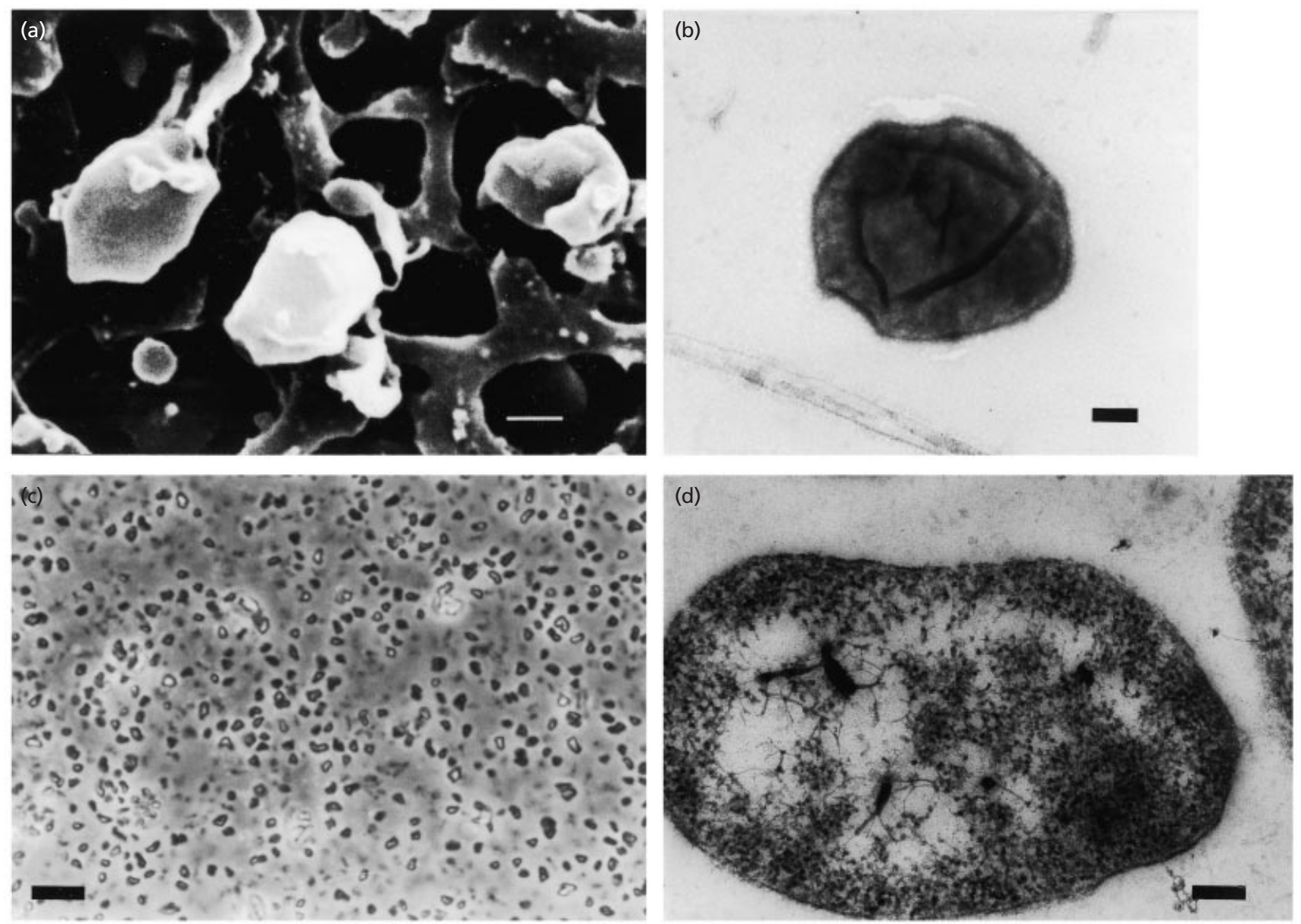

Fig. 1. (a) Scanning electron micrograph of strain $P 2 F 9704 a^{\top}$ (bar, $0.33 \mu \mathrm{m}$ ). (b) Negatively stained cell of strain $P 2 F 9704 a^{\top}$

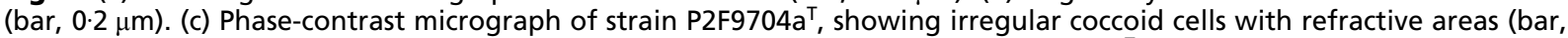
$2.5 \mu \mathrm{m}$ ). (d) Transmission electron micrograph of an ultrathin section of strain $\mathrm{P}^{\mathrm{F} 9704 \mathrm{a}^{\top}}$ (bar, $\left.0 \cdot 1 \mu \mathrm{m}\right)$.

Table 1. Characteristics of Methanocalculus species

Strains: 1, strain P2F9704a ${ }^{\mathrm{T}}$; 2, strain P2F9705; 3, Methanocalculus halotolerans SEBR 4845 ${ }^{\mathrm{T}}$; 4, Methanocalculus pumilus MHT$1^{\mathrm{T}}$. All strains are irregular cocci, use $\mathrm{H}_{2} / \mathrm{CO}_{2}$ and sodium formate as substrates for methanogenesis, require acetate, and are lysed by addition of SDS.

\begin{tabular}{|lllll|}
\hline Character/reference & \multicolumn{1}{c}{$\mathbf{1}$} & \multicolumn{1}{c|}{$\mathbf{2}$} & \multicolumn{1}{c|}{$\mathbf{4}$} \\
\hline Cell size $(\mu \mathrm{m})$ & $0 \cdot 9-1 \cdot 4$ & $0 \cdot 8-1 \cdot 4$ & $0 \cdot 8-1 \cdot 0$ & $0 \cdot 8-1 \cdot 0$ \\
Flagella & - & + & + & - \\
Refractive area* & Yes & Yes & Yes & ND \\
Temp. optimum/range $\left({ }^{\circ} \mathrm{C}\right)$ & $37 / 25-42$ & $37 / 28-37$ & $38 / 25-45$ & $35 / 24-45$ \\
$\mathrm{pH}$ optimum/range & $6 \cdot 7 / 5 \cdot 6-8 \cdot 3$ & $7 \cdot 1 / \mathrm{ND}$ & $7 \cdot 6 / 7 \cdot 0-8 \cdot 4$ & $6 \cdot 5-7 \cdot 5 / \mathrm{ND}$ \\
NaCl optimum/range $(\%)$ & $0 \cdot 5 / 0-4$ & $1 \cdot 0 / 0-3$ & $5 \cdot 0 / 0-12$ & $1 \cdot 0 / 0-7$ \\
S-layer $\left(M_{\mathrm{r}}\right)$ & $111800 ; 95100$ & ND & 91800 & 94300 \\
Habitat & Estuary & Estuary & Oilfield & Waste disposal site \\
Reference & This study & This study & Ollivier et al. $(1998)$ & Mori et al. $(2000)$ \\
\hline
\end{tabular}

ND, Not determined.

* Refractive area observed by phase microscopy. 

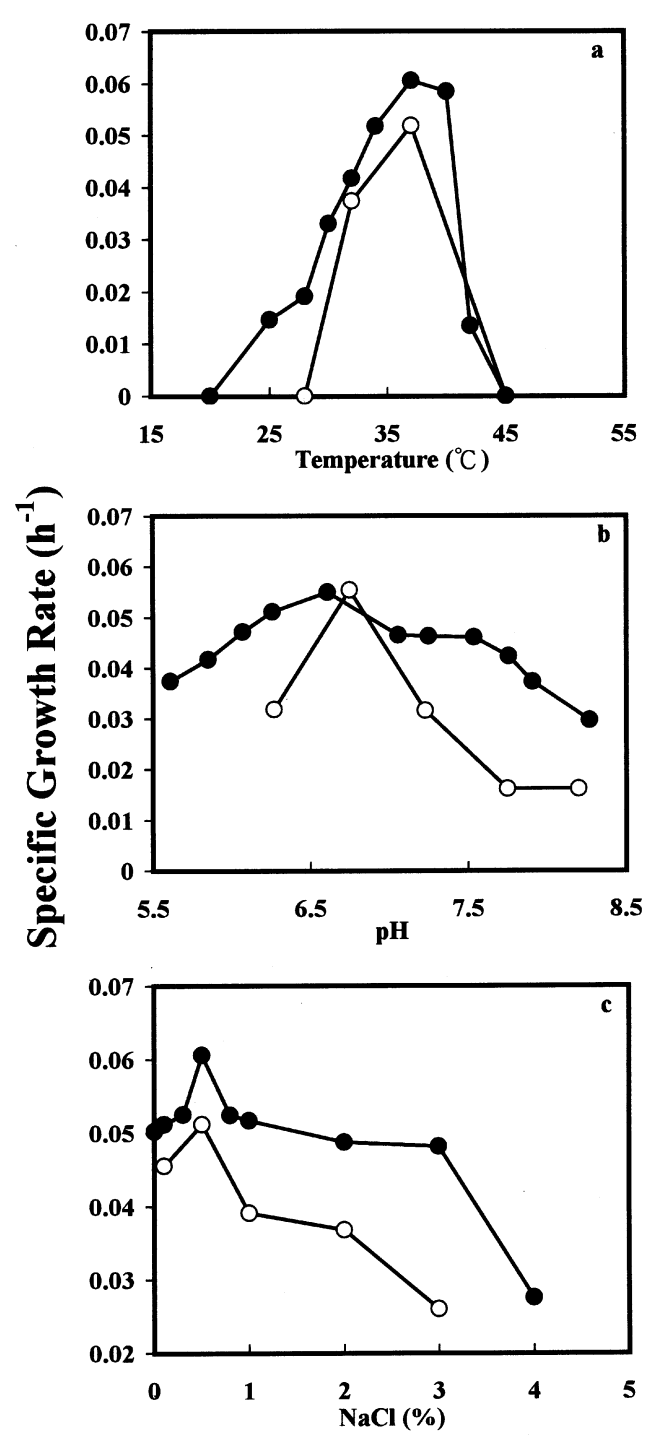

Fig. 2. Influence of temperature (a), $\mathrm{pH}(\mathrm{b})$ and salinity (c) on the growth of strain P2F9704a ${ }^{\top}$ in $\mathrm{MB}$ medium $(\mathrm{O})$ and in $\mathrm{MB} / \mathrm{W}$ medium (O) with formate as the catabolic substrate. Specific growth rates were calculated from methane production, and are the means of triplicate cultures.

\section{Growth substrates, requirements and optimal growth conditions}

Strain P2F9704a ${ }^{\mathrm{T}}$ can use only formate and $\mathrm{H}_{2}+\mathrm{CO}_{2}$ to produce methane. Under an $\mathrm{N}_{2} / \mathrm{CO}_{2}$ atmosphere, it could not produce methane from acetate, methanol, trimethylamine, ethanol, 2-propanol, iso-butanol or 2butanol. Acetate $(20 \mathrm{mM})$ was required for cell growth. The doubling times of strain $\mathrm{P} 2 \mathrm{~F} 9704 \mathrm{a}^{\mathrm{T}}$ in minimal medium $(\mathrm{MM} / \mathrm{W}$ ) and in $\mathrm{MB} / \mathrm{W}$ (containing yeast extract and tryptone) with formate plus acetate were $8 \cdot 2$ and $7 \cdot 1 \mathrm{~h}$, respectively. Without the addition of acetate in the $\mathrm{MM} / \mathrm{W}$ medium, cells could not be subcultured more than twice.

The optimal growth temperature for strain P2F9704a ${ }^{\mathrm{T}}$ was $37^{\circ} \mathrm{C}$, but it did not grow at temperatures below

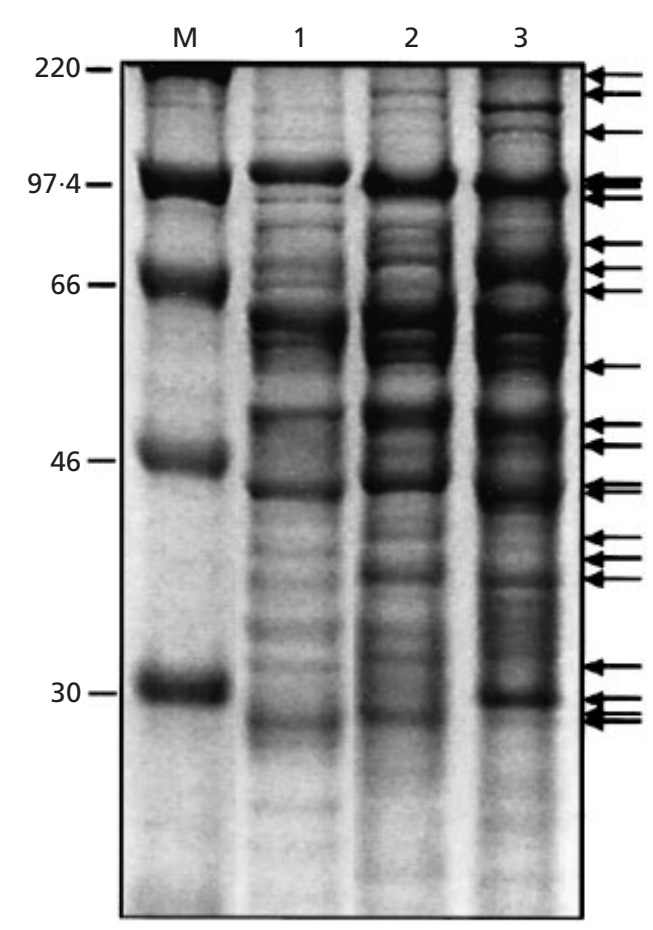

Fig. 3. Cell-protein profile of Methanocalculus species determined by SDS-PAGE. Lane 1, strain P2F9704a'; lane 2, Methanocalculus halotolerans; lane 3, Methanocalculus pumilus. Lane $\mathrm{M}$, protein marker. Arrows indicate polypeptide bands with significant differences between strain P2F9704a and the other Methanocalculus species.

$28^{\circ} \mathrm{C}$ or above $45^{\circ} \mathrm{C}$ (Fig. 2a). Upon the addition of the trace element tungsten, the optimal growth temperature remained at $37^{\circ} \mathrm{C}$. However, the minimum growth temperature was extended to $25^{\circ} \mathrm{C}$ (Fig. 2a). Cells grew over a wide range of $\mathrm{pH}$, from $6 \cdot 3$ to $8 \cdot 3$; the optimal $\mathrm{pH}$ for growth was $6 \cdot 7$, growth at higher $\mathrm{pH}$ values being poor (Fig. 2b). The addition of tungsten increased the $\mathrm{pH}$ tolerance of strain $\mathrm{P} 2 \mathrm{~F} 9704 \mathrm{a}^{\mathrm{T}}$, and cells grew well over a pH range of 5.6 to $8 \cdot 3$ (Fig. 2b). Strain P2F9704a ${ }^{\mathrm{T}}$ tolerated $\mathrm{NaCl}$ concentrations of 0.1 and $3.0 \%$. The optimal salt concentration for growth was $0.5 \%$ (Fig. 2c). A similar tungsten effect also occurred with regard to salt tolerance. With the addition of tungsten, the optimal salt concentration for growth remained at $0.5 \%$, but cells also grew well within a $0-4 \% \mathrm{NaCl}$ range (Fig. 2c). Growth was not observed at $6 \% \mathrm{NaCl}$. Although tungsten was not required for cell growth, it stimulated cell growth slightly. Under optimal growth conditions $(0.5 \%$ $\mathrm{NaCl}, \mathrm{pH} 6.7$ and $37^{\circ} \mathrm{C}$ ), the doubling times of strain $\mathrm{P} 2 \mathrm{~F} 9704 \mathrm{a}^{\mathrm{T}}$ grown in $\mathrm{MB}$ and $\mathrm{MB} / \mathrm{W}$ were 13.4 and $11 \cdot 4 \mathrm{~h}$, respectively.

\section{Whole-cell protein analysis}

Whole-cell protein from strain P2F9704a ${ }^{\mathrm{T}}$, Methanocalculus halotolerans and Methanocalculus pumilus was extracted and analysed. As indicated in Fig. 3, the 


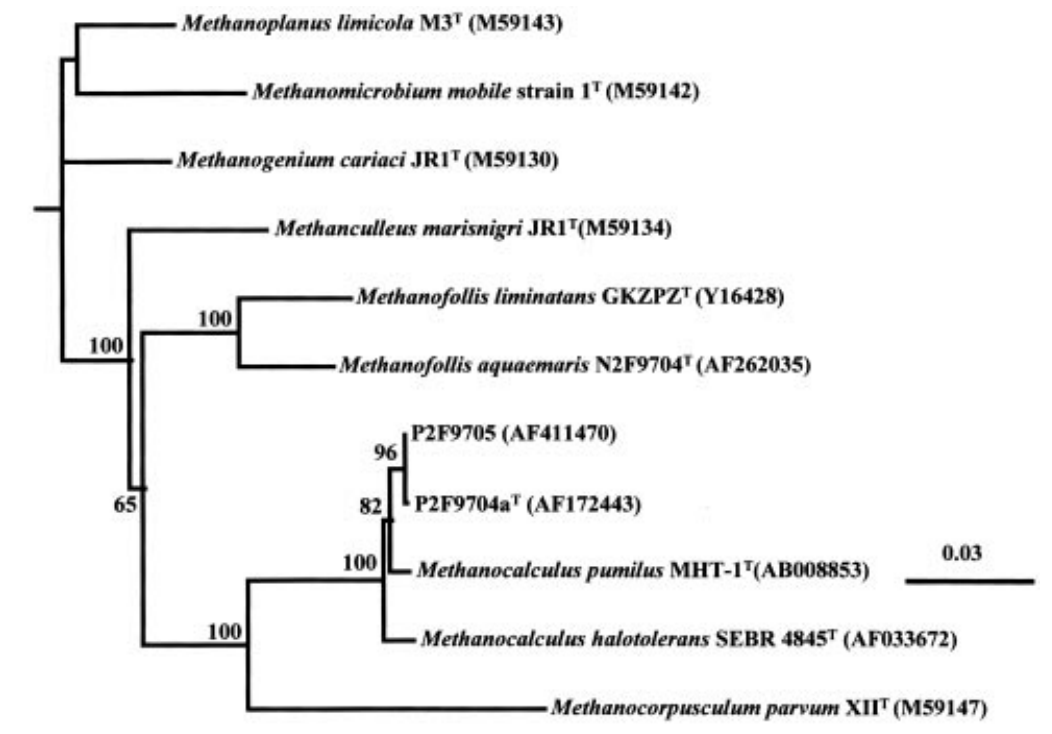

Fig. 4. Phylogenetic relationships of strains

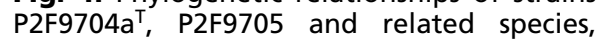
based on the 16S rRNA gene sequences. The PHYLIP program was used to estimate phylogenic distance from the distancematrix data. Bootstrap values at nodes are the percentages of 500 replicates. Scale bar, base substitutions per 100 bases.

protein profile of $\mathrm{P} 2 \mathrm{~F} 9704 \mathrm{a}^{\mathrm{T}}$ was distinct from those of the other two Methanocalculus species.

\section{S rRNA gene analysis}

The 16S rDNAs of strain P2F9704a ${ }^{\mathrm{T}}$ (1369 nt) and P2F9705 (1260 nt) were sequenced and shown to possess $99.7 \%$ sequence similarity. The phylogenetic tree was constructed using a selection of different methanogen sequences obtained from the GenBank database. These two new isolates were shown to be close relatives of Methanocalculus halotolerans and Methanocalculus pumilus (Fig. 4). The similarities of the $16 \mathrm{~S}$ rDNA sequences of strain $\mathrm{P} 2 \mathrm{~F} 9704 \mathrm{a}^{\mathrm{T}}$ to Methanocalculus pumilus and Methanocalculus halotolerans sequences were $99 \cdot 1$ and $98 \cdot 5$, respectively.

\section{DNA-DNA hybridization}

In DNA-DNA hybridization experiments, the DNA of strain P2F9704a ${ }^{\mathrm{T}}$ exhibited $14 \%$ hybridization with the DNA of Methanocalculus pumilus and $12 \%$ hybridization with the DNA of Methanocalculus halotolerans.

\section{DISCUSSION}

Two mesophilic, hydrogenotrophic methanogens, strains P2F9704a ${ }^{T}$ and $\mathrm{P} 2 \mathrm{~F} 9705$, were isolated from water samples from an estuarine environment in Eriln Shi, Taiwan. Comparison of $16 \mathrm{~S}$ rRNA sequences indicated that these two new strains were phylogenetically related to Methanocalculus pumilus and Methanocalculus halotolerans and distinct from the other known methanogens (less than 91\% similarity). Characteristics that differentiate strains $\mathrm{P} 2 \mathrm{~F} 9704 \mathrm{a}^{\mathrm{T}}$ and P2F9705 from Methanocalculus halotolerans and Methanocalculus pumilus are listed in Table 1. They are all mesophilic, neutrophilic methanogens that use only formate and $\mathrm{H}_{2}+\mathrm{CO}_{2}$ as catabolic substrates and require acetate for cell growth. The $16 \mathrm{~S}$ rRNA sequence similarities of strain $\mathrm{P} 2 \mathrm{~F} 9704 \mathrm{a}^{\mathrm{T}}$ with respect to Methanocalculus pumilus and Methanocalculus halotolerans were 99.1 and $98.5 \%$, respectively. Although, these differences in the 16S rRNA sequences do not strongly support the formation of a new species (Stackebrandt \& Goebel, 1994), the formation of a new species is strongly indicated by the DNA-DNA hybridization analysis that revealed $14 \%$ relatedness with the DNA to Methanocalculus pumilus and $12 \%$ relatedness to that of Methanocalculus halotolerans. Additionally, the molecular mass of the S-layer protein (Table 1), the whole-cell protein profiles (Fig. 3) and the optimal salt range for growth of strain $\mathrm{P} 2 \mathrm{~F} 9704 \mathrm{a}^{\mathrm{T}}$ were different from those of Methanocalculus halotolerans and Methanocalculus pumilus. These phylogenetic, phenotypic and physiological distinctions indicate that strain P2F9704a ${ }^{\mathrm{T}}$ may represent a new Methanocalculus species, which we have named Methanocalculus taiwanensis (as it is the first new methanogenic species isolated from Taiwan). In addition, strain P2F9705 (= OCM 672) is a member of the same (or a closely related) species.

The stimulatory effect of tungsten on the growth of methanogens was first reported in the late 1970s for Methanococcus vannielii (Jones \& Stadtman, 1977). Cell growth was dramatically enhanced by the addition of tungsten when formate was the carbon and energy source, but not during growth on $\mathrm{H}_{2}$ and $\mathrm{CO}_{2}$. Within the order Methanomicrobiales, growth stimulated by tungsten has been described for Methanofollis liminatans (Zellner et al., 1990, 1999) and Methanofollis aquaemaris (Lai \& Chen, 2001). Also, growth that required tungsten has been reported for Methanoculleus palmolei (Zellner et al., 1998), Methanocorpusculum parvum (Zellner et al., 1987) and Methanofollis tationis (Zabel et al., 1984). The effect of tungsten in Methanocalculus has not been observed before, and 
our observation of strain $\mathrm{P} 2 \mathrm{~F} 9704 \mathrm{a}^{\mathrm{T}}$ revealed that tungsten was not required but does slightly stimulate cell growth. Moreover, the addition of tungsten increased cells' capacity to tolerate extremes of environmental $\mathrm{pH}$, temperature and salt (Fig. 2). These results indicated that tungsten is not only important in the survival of cells but also in facing environmental challenges.

Most halotolerant and halophilic methanogenic species that have been described are methylotrophic (Boone et al., 1993a; Zhilina, 1986), and it was suggested by Ollivier et al. (1994) that the use of methylotrophic substrates by methane-producing bacteria in halophilic environments predominates over $\mathrm{H}_{2}$ and acetate utilization. Methanocalculus halotolerans grows optimally at $5 \% \mathrm{NaCl}(\mathrm{w} / \mathrm{v})$ and tolerates up to $12 \% \mathrm{NaCl}$, a range which is the widest reported, to date, for any hydrogenotrophic methanogen (Ollivier et al., 1998). Therefore, Ollivier et al. (1998) described the new genus Methanocalculus on the basis of this salt tolerance. However, Mori et al. (2000) recently reported that Methanocalculus pumilus, a heavy-metaltolerant methanogen isolated from a waste-disposal site, grew optimally at $1.0 \% \mathrm{NaCl}$ and only tolerated a salt range of $0-7 \% \mathrm{NaCl}$. Here, we report two more Methanocalculus isolates, strains $\mathrm{P} 2 \mathrm{~F} 9704 \mathrm{a}^{\mathrm{T}}$ and P2F9705, from the estuarine environment of Eriln Shi, Taiwan. The optimal salt concentrations for the growth of strains P2F9704a ${ }^{\mathrm{T}}$ and $\mathrm{P} 2 \mathrm{~F} 9705$ were $0.5 \%$ and $1.0 \%$, respectively, and these two Methanocalculus strains tolerate $\mathrm{NaCl}$ concentrations only up to $4 \%$. Moreover, we have also isolated and characterized two new Methanocalculus species from aquaculture fishponds (Lai \& Lin, 2001). Their optimal concentration of $\mathrm{NaCl}$ for growth is $1.0 \%$, but they can tolerate up to $12 \% \mathrm{NaCl}$. The occurrence of these new species indicated that Methanocalculus is widely distributed in nature and is highly diversified in terms of adaptation to salt.

\section{Description of Methanocalculus taiwanensis sp. nov.}

Methanocalculus taiwanensis (tai.wa.nen'sis. N.L. adj. taiwanensis of Taiwan, indicating the source of the type strain).

Irregular coccoid cells that stain Gram-negative, are non-motile, and are $0.9-1.4 \mu \mathrm{m}$ in diameter. Lysed by $0 \cdot 1 \mathrm{~g} \mathrm{SDS}^{-1}$. Cells are resistant to ampicillin, penicillin, kanamycin, spectinomycin and tetracycline but sensitive to chloramphenicol. Catabolic substrates used include $\mathrm{H}_{2} / \mathrm{CO}_{2}$ and formate, but not acetate, methanol, trimethylamine, ethanol, 2-propanol, isobutanol or 2-butanol. Acetate is required for cell growth. Tungsten was not required but stimulated growth; addition of tungsten as a trace element greatly extends the ranges of temperature, $\mathrm{pH}$ and salt allowing growth. Optimal growth occurs in the presence of $0.5 \% \mathrm{NaCl}(\mathrm{w} / \mathrm{v})$ at $\mathrm{pH} 6.7$ at $37^{\circ} \mathrm{C}$. Type strain is strain P2F9704a ${ }^{\mathrm{T}}\left(=\mathrm{OCM} 671^{\mathrm{T}}=\mathrm{CCRC}\right.$ $16182^{\mathrm{T}}=\mathrm{DSM} 14663^{\mathrm{T}}$ ), which was isolated from the water of an estuary in Eriln Shi near Wong-Kong, Taiwan. The reference strain is strain P2F9705.

\section{ACKNOWLEDGEMENTS}

The authors would like to thank Pei-Chi Chao and YenShiun Lin from the Regional Instruments Centre at National ChungHsing University for operating the electron microscopes. We thank Dr Pi-Fang Linda Chang from the department of Plant Pathology of National ChungHsing University for help and supplies during the DNA-DNA hybridization experiments. This work was partially supported by the Council of Agriculture, The Executive Yuan of the Republic of China. M.-C.L. and S.-C.C. contributed equally to this paper.

\section{REFERENCES}

Balch, W. E., Fox, G. E., Margum, L. J., Woese, C. R. \& Wolfe, R. S. (1979). Methanogens: reevaluation of a unique biological group. Microbiol Rev 43, 260-296.

Boone, D. R. \& Whitman, W. B. (1988). Proposal of minimal standards for describing new taxa of methanogenic bacteria. Int J Syst Bacteriol 38, 212-219.

Boone, D. R., Mathrani, I. M., Liu, Y., Menaia, J. A. G. F., Mah, R. A. \& Boone, J. E. (1993a). Isolation and characterization of Methanohalophilus portucalensis sp. nov. and DNA reassociation study of the genus Methanohalophilus. Int J Syst Bacteriol 43, 430-437.

Boone, D. R., Whitman, W. B. \& Rouvière, P. (1993b). Diversity and taxonomy of methanogens. In Methanogenesis, pp. 35-80. Edited by J. G. Ferry. New York: Chapman \& Hall.

Felsenstein, J. (1995). PHYLIP (Phylogenetic Inference Package) version 3.57c. Seattle: University of Washington.

Ferguson, T. J. \& Mah, R. A. (1983). Isolation and characterization of an $\mathrm{H}_{2}$-oxidizing thermophilic methanogen. Appl Environ Microbiol 45, 265-274.

Ferry, J. G. (1997). Methane: small molecules, big impact. Science 278, 1413-1414.

Huber, H., Thomm, M., König, H., Thies, G. \& Stetter, K. O. (1982). Methanococcus thermolithotrophicus, a novel thermophilic lithotrophic methanogen. Arch Microbiol 132, 47-50.

Garcia, J.-L., Patel, B. K. C. \& Ollivier, B. (2000). Taxonomic, phylogenic, and ecological diversity of methanogenic archaea. Anaerobe 6, 205-226.

Jarrell, K. F. D., Hebert, F. A. M. \& Kalmokoff, M. L. (1992). A general method of isolating high molecular weight DNA from methanogenic archaea (archaebacteria). Can J Microbiol 38, 65-68.

Johnson, J. L. (1985). DNA reassociation and DNA hybridization of bacterial nucleic acids. Methods Microbiol 18, 33-74.

Jones, J. B. \& Stadtman, T. C. (1977). Methanococcus vannielii: culture and effects of selenium and tungsten on growth. J Bacteriol 130, 1404-1406

Jones, W. J., Leigh, J. A., Mayer, F., Woese, C. R. \& Wolfe, R. S. (1983). Methanococcus jannaschii sp. nov., an extremely thermophilic methanogen from submarine hydrothermal vent. Arch Microbiol 136, 254-261.

Jones, W. J., Nagle, J. D., Jr \& Whitman, W. B. (1987). Methanogens and the diversity of Archaebacteria. Microbiol Rev 51, 135-177.

König, H. (1995). Isolation and analysis of cell walls from methanogenic archaea. In Archaea: a Laboratory Manual, vol. 2, Methanogens, pp. 315-328. Edited by K. R. Sowers \& H. T. Schreier. Cold Spring Harbor, NY: Cold Spring Harbor Laboratory.

Laemmli, U. (1970). Cleavage of structural proteins during the assembly of the head of bacteriophage T4. Nature 227, 680-685.

Lai, M.-C. \& Chen, S.-C. (2001). Methanofollis aquaemaris sp. nov., a methanogen isolated from an aquaculture fish pond. Int $J$ Syst Evol Microbiol 51, 1873-1880. 
Lai, M.-C. \& Lin, C.-C. (2001). Isolation and characterization of a new methanogen from an aquaculture fishpond, I-56. In Abstracts of the 101st General Meeting of the American Society for Microbiology. Washington, DC: American Society for Microbiology.

Lai, M.-C. \& Shih, C.-J. (2001). Characterization of Methanococcus voltaei strain P2F9701a, a new methanogen isolated from estuarine environment. Curr Microbiol 42, 432-437.

Lai, M.-C., Shu, C.-M., Chiou, M.-S., Hong, T.-Y., Chuang, M.-J. \& Hua, J. J. (1999). Characterization of Methanosarcina mazei strain N2M9705 isolated from an aquaculture fishpond. Curr Microbiol 39, $79-84$.

Lai, M.-C., Shu, C.-M., Chen, S.-C., Lai, L.-J., Chiou, M.-S. \& Hua, J. J. (2000). Methanosarcina mazei strain O1M9704, methanogen with novel tubule isolated from estuarine environment. Curr Microbiol 41, 15-20.

Maidak, B. L., Olsen, G. J., Larsen, N., Overbeek, R., McCaughey, M. J. \& Woese, C. R. (1996). The ribosomal database project (RDP). Nucleic Acids Res 24, 82-85.

Mori, K., Yamamoto, H., Kamagata, Y., Hastu, M. \& Takamizawa, K. (2000). Methanocalculus pumilus sp. nov., a heavy-metal-tolerant methanogen isolated from a waste-disposal site. Int J Syst Evol Microbiol 50, 1723-1729.

Ollivier, B., Caumette, P., Garcia, J.-L. \& Mah, R. A. (1994). Anaerobic bacteria from hypersaline environments. Microbiol Rev 58, 27-38.

Ollivier, B., Fardeau, M.-L., Cayol, J.-L., Magot, M., Patel, B. K. C., Prensier, G. \& Garcia, J.-L. (1998). Methanocalculus halotolerans gen. nov., sp. nov., isolated from an oil-producing well. Int $J$ Syst Bacteriol 48, 821-828.

Rouvière, P., Mandelco, L., Winker, S. \& Woese, C. R. (1992). A detailed phylogeny for the Methanomicrobiales. Syst Appl Microbiol 15, 363-371.

Sambrook, J. \& Russell, D. W. (2001). Molecular Cloning: a Laboratory Manual, 3rd edn. Cold Spring Harbor, NY: Cold Spring Harbor Laboratory.

Sowers, K. R. \& Noll, K. M. (1995). Techniques for anaerobic growth. In Archaea: a Laboratory Manual, vol. 2, Methanogens, pp. 15-48.
Edited by K. R. Sowers \& H. T. Schreier. Cold Spring Harbor, NY: Cold Spring Harbor Laboratory.

Stackebrandt, E. \& Goebel, B. M. (1994). Taxonomic note: a place for DNA-DNA reassociation and 16S rRNA sequence analysis in the present species definition in bacteriology. Int J Syst Bacteriol 44, 846-649.

Stetter, K. O., Huber, R., Blochl, E., Kurr, M., Eden, R. D., Fielder, M., Cash, H. \& Vance, L. (1993). Hyperthermophilic Archaea are thriving in deep North Sea and Alaskan reservoirs. Nature 365, 743-745.

Wolfe, R. S. (1996). 1776-1996: Alessandro Volta's combustible air. ASM News 62, 529-534.

Wolin, E. A., Wolin, M. J. \& Wolfe, R. S. (1963). Formation of methane by bacterial extracts. J Biol Chem 238, 2882-2886.

Zabel, H. P., König, H. \& Winter, J. (1984). Isolation and characterization of a new coccoid methanogen, Methanogenium tationis spec. nov. from a solfataric field on Mount Tatio. Arch Microbiol 137, 308-315.

Zellner, G., Alten, C., Stackebrandt, E., Conway de Macario, E. \& Winter, J. (1987). Isolation and characterization of Methanocorpusculum parvum gen. nov., spec. nov., a new tungsten requiring, coccoid methanogen. Arch Microbiol 147, 13-20.

Zellner, G., Sleytr, U. B., Messner, P., Kneifel, H. \& Winter, J. (1990). Methanogenium liminatans spec. nov., a new coccoid, mesophilic methanogen able to oxidize secondary alcohols. Arch Microbiol 153, 287-293.

Zellner, G., Messner, P., Winter, J. \& Stackebrandt, E. (1998). Methanoculleus palmolei sp. nov., an irregularly coccoid methanogen from an anaerobic digester treating wastewater of a palm oil plant in North-Samatra, Indonesia. Int J Syst Bacteriol 48, 1111-1117.

Zellner, G., Boone, D. R., Keswani, J., Whitman, W. B., Woese, C. R., Hagelstein, A., Tindall, B. J. \& Stackebrandt, E. (1999). Reclassification of Methanogenium tationis and Methanogenium liminatans as Methanofollis tationis gen. nov., comb. nov. and Methanofollis liminatans comb. nov. and description of a new strain of Methanofollis liminatans. Int J Syst Bacteriol 49, 247-255.

Zhilina, T. N. (1986). Methanogenic bacteria from hypersaline environments. Syst Appl Microbiol 7, 216-222. 